\title{
Biological Ice Nucleators in Snow Samples from Greece
}

\author{
Dimitrios G. Georgakopoulos
}

Laboratory of General and Agricultural Microbiology, Department of Crop Science, Agricultural University of Athens, Iera Odos 75, 11855 Athens, Greece; dgeorga@aua.gr

\begin{abstract}
The formation of precipitation in clouds is initiated by inorganic and organic/biological ice nuclei. Certain species of bacteria and fungi are known to act as efficient biological ice nuclei at temperatures between -10 and $0{ }^{\circ} \mathrm{C}$. Biological ice nuclei have been found and characterized in precipitation samples (snow, rain, and hail). We investigated the presence of warm temperature biological ice nuclei in 17 fresh snow samples from Greece and isolated and partially characterized ice nucleation active bacteria from these. All snow samples contained particles or other material active as ice nuclei at $-9{ }^{\circ} \mathrm{C}$ in concentrations ranging from 3 to 943 nuclei/L. The numbers of this class of ice nuclei were reduced or eliminated after incubating snowmelt concentrates at $100{ }^{\circ} \mathrm{C}$ for $15 \mathrm{~min}$ and by treatment with lysozyme, a bacterial cell wall-degrading enzyme. These findings indicate the presence of microbial ice nuclei in snow samples from Greece. We also isolated ice nucleation active bacteria from some of the samples. These bacteria belong to genus Pseudomonas and are common on plants and soil. This is the first report on biological ice nuclei in precipitation samples from Greece.
\end{abstract}

Keywords: snow; bacteria; biological ice nuclei

check for

updates

Citation: Georgakopoulos, D.G. Biological Ice Nucleators in Snow Samples from Greece. Atmosphere 2021, 12, 1461. https://doi.org/ $10.3390 /$ atmos12111461

Academic Editor: Salvatore Romano

Received: 10 October 2021

Accepted: 2 November 2021

Published: 5 November 2021

Publisher's Note: MDPI stays neutral with regard to jurisdictional claims in published maps and institutional affiliations.

Copyright: (C) 2021 by the author. Licensee MDPI, Basel, Switzerland. This article is an open access article distributed under the terms and conditions of the Creative Commons Attribution (CC BY) license (https:// creativecommons.org/licenses/by/ $4.0 /)$.

\section{Introduction}

Biological ice nucleation was first discovered in the 1970s, almost simultaneously but independently, by atmospheric scientists investigating soil and plants as sources for atmospheric ice nuclei found in hail, and by plant pathologists investigating factors that enhance frost damage on crops [1]. The first characterized biological ice nuclei were bacteria from the aerial plant surface of the plant pathogenic species Pseudomonas syringae. The ice nucleation activity of this bacterium (and of other species discovered later) has been characterized, and the genes and gene products controlling this activity have been identified [2]. The factor for the ice nucleation activity of these bacteria, a rare property in the microbial world, is a protein located in their outer membrane. The diversity of biological ice nuclei has increased after the identification of fungi [3], lichens [4,5], pollen [6-8], Archaea [9], and viruses [10] with the potential to act as ice nuclei.

Microorganisms disseminate aerially from their natural habitats and have been isolated from the atmosphere up to several kilometers above ground. Aerial dissemination of pathogenic microorganisms in bioaerosols is significant for the epidemiology of human, animal, and plant diseases. However, the discovery of bacterial ice nucleation led scientists to speculate about the potential involvement of ice nucleation active microorganisms in atmospheric processes. Sands and colleagues proposed a "bioprecipitation" cycle, where crops harboring large populations of ice nucleation active bacteria serve as sources of aerial bacterial ice nuclei involved in the formation of precipitation in clouds, which enhances plant growth and crops, enabling in turn the development of new epiphytic bacterial populations acting as ice nuclei in the atmosphere [11,12]. The actual significance of bioprecipitation in nature is under increasing investigation. Moore et al. [13] showed a clear correlation between climatic and landscape changes and the frequency of rainfall in areas of the United States, a possible effect of several different biological processes on climate.

The presence of microbial ice nuclei has been established in cloud water [14], rain, and snow [15-17], and microbial ice nuclei have been proven to form ice in simulated cloud 
conditions [18-20]. Christner et al. [16,17] demonstrated that the majority of ice nuclei in snow samples active at $-10{ }^{\circ} \mathrm{C}$ were eliminated by heating at $100{ }^{\circ} \mathrm{C}$ and by lysozyme treatment (an enzyme degrading bacterial cell walls and causing cell lysis) of snowmelt concentrates, an indication of the biological/microbial nature of this class of ice nuclei in snow.

The rationale for this study was to investigate fresh fallen snow, presumed to be uncontaminated from ground sources, as a point in the "bioprecipitation" cycle.

\section{Materials and Methods}

\subsection{Snow Samples}

Seventeen snow samples were collected in central Greece during the winters of 2012 to 2018. All sampling sites were as far away as possible from anthropogenic interferences. Eleven were from sites outside the limits of the Mount Parnassos ski center, at the alpine zone in altitudes over $2000 \mathrm{~m}$; four from various sites at Mt. Parnitha; three from Mt. Kithaironas. Sites in the latter two were close to forests, at altitudes of 1300-1400 m. All samples were collected within $24 \mathrm{~h}$ from a snowfall. Collection was carried out by hand using a $6 \mathrm{~L}$ zippered plastic freezer bag turned inside out. Initially, top snow was removed, and the underlying snow was collected using a fresh bag. Snow samples were transported to the laboratory in a cooler on the same day and allowed to thaw at $4{ }^{\circ} \mathrm{C}$.

\subsection{Snow Sample Processing}

Snow samples were processed essentially according to Christner et al. [17]. After thawing, the volume of each thawed snow sample was measured. Samples were then filtered through sterile $45 \mathrm{~mm}$-diameter, $0.2 \mu \mathrm{m}$-pore-size nucleopore filters fitted on a Millipore water filtration unit fitted with double-sterilized glass funnels, operated by an air pump. The filtration was carried out inside a biosafety level-II laminar flow cabinet previously disinfected with ultraviolet light for one hour. Filters were aseptically removed with flame-sterilized tools, transferred in sterile $2 \mathrm{~mL}$ Eppendorf tubes containing $2 \mathrm{~mL}$ sterile double-distilled water and vortexed vigorously for two minutes. The $2 \mathrm{~mL}$ filter washings were subsequently subdivided into ten $200 \mu \mathrm{L}$ aliquots in Eppendorf tubes, which were placed into a cooling bath set at $-9{ }^{\circ} \mathrm{C}$ for three minutes, to identify the aliquots containing ice nuclei active at this temperature. The $-9{ }^{\circ} \mathrm{C}$ temperature was selected, because mostly microbial ice nuclei are active at this temperature, and it is sufficiently low to allow the activity of the weaker microbial ice nuclei.

Frozen aliquots were allowed to thaw at room temperature. The tubes with frozen aliquots were divided into three groups. If less than three aliquots from a snow sample froze, the pooled filter washing was divided into three parts. The first group of aliquots received a solution of lysozyme to a final concentration of $3 \mathrm{mg} / \mathrm{mL}$ and were incubated at $4{ }^{\circ} \mathrm{C}$ for $72 \mathrm{~h}$. Lysozyme is an enzyme that breaks down the bacterial cell wall, thus destroying bacterial cells. Tubes from the second group of aliquots were placed in a heater set at $100{ }^{\circ} \mathrm{C}$ for $15 \mathrm{~min}$. At this temperature, all known microbial ice nuclei are inactivated, because this temperature kills most microorganisms and initiates cell lysis. The third group of aliquots did not receive any lysozyme or heat treatment and were used to determine the background concentration of ice nuclei in snow samples. A negative control consisting of sterile double-distilled water, which was processed in the same way (including the plastic bag used to collect and carry snow samples), was included.

After the lysozyme and heat treatment, the ice nucleation activity of all aliquots was determined at $-9{ }^{\circ} \mathrm{C}$ with Vali's droplet freezing method [21]. Three tenfold serial dilutions of the initial aliquot were made ( $100 \mu \mathrm{L}$ in $900 \mu \mathrm{L}$ sterile distilled water), and 20 droplets of $10 \mu \mathrm{L}$ were placed on a paraffin-coated aluminum foil. The foil was floated on the surface of a cooling bath set at $-9{ }^{\circ} \mathrm{C}$, and the number of frozen droplets was recorded after three minutes. Droplets of sterile distilled water were also included in the experiment as a negative control. Ice nuclei in samples were calculated as described by Vali [21]. 


\subsection{Isolation and Characterization of Bacteria from Snow Samples}

A collection of bacterial isolates belonging to the genus Pseudomonas was made from the untreated aliquots of snow samples. The remaining quantity of frozen aliquots was dispersed onto Petri dishes containing BCBRVB, a modified King's B substrate [22] (100 $\mu \mathrm{L}$ per dish). This medium facilitates the isolation of bacteria from the genus Pseudomonas, which encompasses most known bacterial ice nuclei. Plates were incubated for 48 $\mathrm{h}$ at $28^{\circ} \mathrm{C}$. Petri dishes were then placed under an ultraviolet lamp emitting at $280 \mathrm{~nm}$, to identify the fluorescent colonies characteristic of the genus Pseudomonas. All fluorescent colonies were purified by streaking onto the same substrate. After $48 \mathrm{~h}$, plates were transferred to a refrigerator at $4{ }^{\circ} \mathrm{C}$ and left for 3 days to enhance any ice nucleation activity they might possess. After this incubation, a suspension of bacteria from one bacterial colony was made in $100 \mu \mathrm{L}$ of sterile distilled water to determine the initial temperature of the ice nucleation activity of each isolate. This was carried out by distributing $10 \mu \mathrm{L}$ droplets of each bacterial suspension on paraffin-coated aluminum foil, which was then placed on a cooling bath set at $0{ }^{\circ} \mathrm{C}$. The temperature of the bath was lowered, and the ice nucleation activity of each isolate was recorded one minute after the temperature of the bath dropped by one negative degree $\mathrm{C}$, until $-9^{\circ} \mathrm{C}$. The temperature at which one or more droplets froze was recorded. A negative control consisting of sterile distilled water was included in the experiment.

Ice nucleation active isolates were also examined for presence of cytochrome c oxidase, a taxonomic tool for Pseudomonas [23], and for their potential pathogenicity on plants with the hypersensitivity test on tobacco leaves [24].

\section{Results}

\subsection{Ice Nuclei in Snow Samples}

All snow samples except one exhibited ice nucleation activity at $-9{ }^{\circ} \mathrm{C}$. The concentration of ice nuclei in snowmelt ranged from 3 to 943 nuclei/L. In 15 out of 17 samples, all or almost all ice nuclei active at $-9^{\circ} \mathrm{C}$ were reduced or eliminated after heat treatment of the snowmelt concentrates by incubation at $100{ }^{\circ} \mathrm{C}$. Similarly, lysozyme treatment reduced or eliminated the concentration of ice nuclei active at $-9^{\circ} \mathrm{C}$ in 16 out of 17 samples. The effects of lysozyme and heat on the concentration of ice nuclei in snow samples provide a good indication of the microbial nature of these ice nuclei. More specifically, samples PK112, PK212, PF212, PK32, 10PN1, 10PN2, 10PN3, 10PN4, and KR2 lost all their ice nuclei after the above treatments, indicating that the ice nuclei in these samples were of microbial nature. Samples PF212 and D2 retained their ice nuclei after heat treatment; sample D1 fully retained ice nucleation activity after lysozyme treatment, indicating that this was not of bacterial nature. The cumulative results of the ice nucleation activity of all 17 snow samples, as well as the effect of lysozyme and heat on this activity, are shown in Table 1.

\subsection{Properties of Bacterial Isolates from Snow}

Bacterial strains X1-X12 were isolated from snow samples from Mt. Parnitha and strains X13-X17 from Mt. Parnassos. They were isolated on the BCBRVB substrate that allows the selective growth of bacteria belonging to the genus Pseudomonas, which includes most known species of bacteria with ice nucleation activity. All these isolates were evaluated for their ice nucleation activity, determined as the initial temperature where this activity was observed. This temperature ranged from $-5{ }^{\circ} \mathrm{C}$ for the most ice nucleation active strains to $-9^{\circ} \mathrm{C}$. Two standard strains were included in this test: Pseudomonas syringae strains 31R1 and Cit7 (kindly provided by Professor Steve Lindow, University of California, Berkeley).

All isolates possess the cytochrome c oxidase and did not elicit the hypersensitivity reaction in tobacco leaves. These results indicate that all isolates tentatively belong to Pseudomonas fluorescens, a species that includes bacteria mostly saprophytic, not pathogenic to plants, and widespread in the soil and on the surface of plants. Table 2 shows the cumulative properties of all isolates in this study. 
Table 1. Snow samples showing information about their origin and their ice nucleation activity prior to and after treatment with heat $\left(100{ }^{\circ} \mathrm{C}\right.$ for $\left.15 \mathrm{~min}\right)$ and lysozyme (nd = not done). Numbers have been rounded to the nearest integer. Dates are shown as day/month/year.

\begin{tabular}{|c|c|c|c|c|c|c|c|}
\hline Sample & Origin & Coordinates & Collection Date & Volume & ina/mL Initial & ina/mL Heat & ina/mL Lysozyme \\
\hline PK112 & Parnassos Kellaria & $\begin{array}{l}38.5393 \mathrm{~N}, \\
22.60645 \mathrm{E}\end{array}$ & 20 January 2012 & 618 & 9 & 0 & 0 \\
\hline PK212 & Parnassos Kellaria & $\begin{array}{l}38.5393 \mathrm{~N} \\
22.60645 \mathrm{E}\end{array}$ & 20 January 2012 & 800 & 0 & 0 & 0 \\
\hline PF112 & Parnassos Fterolakka & $\begin{array}{l}38.5641 \mathrm{~N}, \\
22.58497 \mathrm{E}\end{array}$ & 20 January 2012 & 943 & 711 & 0 & 21 \\
\hline PF212 & Parnassos Fterolakka & $\begin{array}{l}38.5641 \mathrm{~N}, \\
22.58497 \mathrm{E}\end{array}$ & 20 January 2012 & 757 & 3 & 3 & 0 \\
\hline PK31 & Parnassos Kellaria & $\begin{array}{l}38.5877 \mathrm{~N}, \\
22.60109 \mathrm{E}\end{array}$ & 1 March 2012 & 426 & 10 & 1 & 1 \\
\hline PK32 & Parnassos Kellaria & $\begin{array}{l}38.5877 \mathrm{~N}, \\
22.60109 \mathrm{E}\end{array}$ & 1 March 2012 & 272 & 3 & 0 & 0 \\
\hline PK33 & Parnassos Kellaria & $\begin{array}{l}38.5877 \mathrm{~N}, \\
22.60109 \mathrm{E}\end{array}$ & 1 March 2012 & 376 & 7 & 0 & 4 \\
\hline 10PN1 & Parnassos Kellaria & $\begin{array}{l}38.5740 \mathrm{~N}, \\
22.61319 \mathrm{E}\end{array}$ & 9 April 2013 & 450 & 112 & 0 & 0 \\
\hline 10PN2 & Parnassos kellaria & $\begin{array}{l}38.5740 \mathrm{~N}, \\
22.61319 \mathrm{E}\end{array}$ & 9 April 2013 & 520 & 33 & 0 & 0 \\
\hline $10 \mathrm{PN} 3$ & Parnassos Fterolakka & $\begin{array}{l}38.5436 \mathrm{~N}, \\
22.59831 \mathrm{E}\end{array}$ & 9 April 2013 & 580 & 241 & 0 & 0 \\
\hline 10PN4 & Parnassos Fterolakka & $\begin{array}{l}38.5436 \mathrm{~N} \\
22.59831 \mathrm{E}\end{array}$ & 9 April 2013 & 580 & 151 & 0 & 0 \\
\hline D1 & Parnitha & $\begin{array}{l}38.1724 \mathrm{~N}, \\
23.72862 \mathrm{E}\end{array}$ & 7 February 2016 & 495 & 484 & 0 & 537 \\
\hline D2 & Parnitha & $\begin{array}{l}38.1724 \mathrm{~N}, \\
23.72862 \mathrm{E}\end{array}$ & 7 February 2016 & 930 & 373 & 376 & 93 \\
\hline KR1 & Kithaironas & $\begin{array}{l}38.1820 \mathrm{~N}, \\
23.27815 \mathrm{E}\end{array}$ & 26 January 2017 & 463 & 41 & 0 & 8 \\
\hline KR2 & Kithaironas & $\begin{array}{l}38.1820 \mathrm{~N}, \\
23.27815 \mathrm{E}\end{array}$ & 26 January 2017 & 427 & 4 & 0 & 0 \\
\hline KRS & Kithaironas & $\begin{array}{l}38.1838 \mathrm{~N} \\
23.24971 \mathrm{E}\end{array}$ & 26 January 2017 & 625 & 68 & 0 & 1 \\
\hline D5 & Parnitha & $\begin{array}{l}38.1716 \mathrm{~N}, \\
23.73404 \mathrm{E}\end{array}$ & 23 January 2018 & 1027 & 39 & nd & 0 \\
\hline
\end{tabular}

Table 2. Ice nucleation and basic microbiological properties of strains isolated from snow samples. Pseudomonas syringae strains 31R1 and Cit7 were included in the experiment as type strains.

\begin{tabular}{ccccc}
\hline Strain & Oxidase Test & Initial Temperature of INA & Hypersensitivity Test & Origin/Snow Sample \\
\hline P. syringae 31R1 & - & -7 & + & type strain \\
P. syringae Cit 7 & - & -3 & + & type strain \\
X1 & + & -6 & - & Parnitha/D1 \\
X2 & + & -7 & - & Parnitha/D1 \\
X3 & + & -5 & - & Parnitha/D1 \\
X4 & + & -5 & - & Parnitha/D2 \\
X5 & + & -6 & - & Parnitha/D2 \\
X6 & + & -7 & - & Parnitha/D4 \\
X7 & + & -6 & - & Parnitha/D4 \\
X8 & + & -6 & - & Parnitha/D4 \\
X9 & + & -7 & - & Parnitha/D5 \\
X10 & + & -7 & - & Parnitha/D5 \\
X11 & + & -5 & - & Parnitha/D5 \\
X12 & + & -7 & - & Parnitha/D5 \\
X13 & + & -8 & - & Parnassos/PF112 \\
X14 & + & -8 & - & Parnassos/PF212 \\
X15 & + & -9 & - & Parnassos/PF212 \\
X16 & + & -7 & - & Parnassos/PK112 \\
X17 & + & -6 & Parnassos/PK112 \\
\hline
\end{tabular}




\section{Discussion}

We investigated the presence of biological ice nuclei in 17 fresh samples of snow collected $24 \mathrm{~h}$ after snowfall from two high-altitude locations in Mt. Parnassos, locations on Mt. Parnitha and Mt. Kithaironas in Greece. Thirteen samples were taken from the alpine zone and four from sites outside conifer forests. We used the approach of Christner et al. (2008) to characterize the nature of ice nuclei in these samples: their activity was tested at $-9{ }^{\circ} \mathrm{C}$, a temperature where few inorganic ice nuclei are active; their sensitivity to heating at $100{ }^{\circ} \mathrm{C}$, where biological ice nuclei are inactivated; their sensitivity to lysozyme, an enzyme breaking down bacterial cell walls causing lysis of cells. All but one of the snow samples contained ice nuclei active at $-9{ }^{\circ} \mathrm{C}$. These ice nuclei were sensitive to lysozyme, as well as heat. This is strong evidence that ice nuclei of a microbial nature were present in these samples. This confirms the initial findings reported by Christner et al. [16,17], as well as subsequent research about the presence of warm temperature biological ice nuclei in fresh snow. The concentrations of ice nuclei active at $-9^{\circ} \mathrm{C}$ are comparable to concentrations reported in other studies [17,25-27].

Isolates of ice nucleation active bacteria belonging to the genus Pseudomonas were obtained from samples from Mt. Parnitha and Mt. Parnassos. They were tentatively classified as Pseudomonas fluorescens by virtue of fluorescent siderophore production on the BCBRVB substrate, their possession of cytochrome c oxidase, and lack of hypersensitivity reaction on tobacco leaves. Isolates X16 and X17 were further characterized by Hill et al. [25]. Their phylogenetic analysis showed that they are closely related to Pseudomonas fluorescens, but also to other unclassified Pseudomonas strains, to Ps. trivialis, Ps. auricularis, and Ps. poae. These species are plant or mushroom associated. Additionally, the ice nucleation gene from these two isolates differs from other known bacterial ice nucleation genes. The bacteria isolated in this study are not known to be pathogenic to humans and animals. In some cases, they can be pathogenic to certain plants. The presence of bacterial ice nuclei in snow samples collected at altitudes from 1400 to $2300 \mathrm{~m}$, at a long distance from agricultural areas, their presumed initial habitat, indicates that these bacteria are present in the atmosphere and either were directly involved in precipitation processes or were present in atmospheric aerosols, which were scavenged by falling snow. The threshold temperature of the ice nucleation activity of our isolates was found to be from -5 to $-9{ }^{\circ} \mathrm{C}$, in agreement with the freezing behavior of our snow sample concentrates.

This is the first investigation of biological ice nuclei in snow samples from Greece. The results support the biological nature of warm temperature ice nuclei in snow and the presence of plant-associated ice nucleation active bacteria in snow.

Funding: This research received no external funding.

Institutional Review Board Statement: Not applicable.

Informed Consent Statement: Not applicable.

Data Availability Statement: Data is contained within the article. Raw data files are available upon request.

Conflicts of Interest: The authors declare no conflict of interest.

\section{References}

1. Upper, C.D.; Vali, G. The Discovery of Bacterial Ice Nucleation and Its Role in the Injury of Plants by Frost. In Biological Ice Nucleation and Its Applications; Lee, R.E., Jr., Warren, G.J., Gusta, L.V., Eds.; APS Press: St. Paul, MN, USA, 1995 ; pp. $29-40$.

2. Warren, G.J. Identification and Analysis of ina Genes and Proteins. In Biological Ice Nucleation and its Applications; Lee, R.E., Jr., Warren, G.J., Gusta, L.V., Eds.; APS Press: St. Paul, MN, USA, 1995; pp. 85-99.

3. Pouleur, S.; Richard, C.; Martin, J.-G.; Antoun, H. Ice Nucleation Activity in Fusarium acuminatum and Fusarium avenaceum. Appl. Environ. Microbiol. 1992, 58, 2960-2964. [CrossRef]

4. Kieft, T.L. Ice Nucleation Activity in Lichens. Appl. Environ. Microbiol. 1988, 54, 1678-1681. [CrossRef]

5. Moffett, B.F.; Getti, G.; Henderson-Begg, S.K.; Hill, T.C.J. Ubiquity of ice nucleation in lichen-Possible atmospheric implications. Lindbergia 2015, 38, 39-43. [CrossRef] 
6. Diehl, K.; Quick, C.; Matthias-Maser, S.; Mitra, S.K.; Jaenicke, R. The ice nucleating ability of pollen: Part I: Laboratory studies in deposition and condensation freezing modes. Atmos. Res. 2001, 58, 75-87. [CrossRef]

7. Diehl, K.; Matthias-Maser, S.; Jaenicke, R.; Mitra, S.K. The ice nucleating ability of pollen: Part II. Laboratory studies in immersion and contact freezing modes. Atmos. Res. 2002, 61, 125-133. [CrossRef]

8. von Blohn, N.; Mitra, S.K.; Diehl, K.; Borrmann, S. The ice nucleating ability of pollen: Part III: New laboratory studies in immersion and contact freezing modes including more pollen types. Atmos. Res. 2005, 78, 182-189. [CrossRef]

9. Creamean, J.M.; Ceniceros, J.E.; Newman, L.; Pace, A.D.; Hill, T.C.; DeMott, P.J.; Rhodes, M.E. Evaluating the potential for Haloarchaea to serve as ice nucleating particles. Biogeosciences 2021, 18, 3751-3762. [CrossRef]

10. Adams, M.; Atanasova, N.; Sofieva, S.; Ravantti, J.; Heikkinen, A.; Brasseur, Z.; Duplissy, J.; Bamford, D.; Murray, B. Data set for ice nucleation by viruses and their potential for cloud glaciation. Biogeosciences 2021, 18, 4431-4444. [CrossRef]

11. Sands, D.C.; Langhans, V.E.; Scharen, A.L.; De Smet, G. The association between bacteria and rain and possible resultant meteorological implications. Idojaras 1982, 86, 148-152.

12. Morris, C.E.; Conen, F.; Huffman, J.; Phillips, V.; Pöschl, U.; Sands, D.C. Bioprecipitation: A feedback cycle linking Earth history, ecosystem dynamics and land use through biological ice nucleators in the atmosphere. Glob. Chang. Biol. 2013, 20, 341-351. [CrossRef]

13. Moore, R.A.; Martinetti, D.; Bigg, E.K.; Christner, B.C.; Morris, C.E. Climatic and landscape changes as drivers of environmental feedback that influence rainfall frequency in the United States. Glob. Chang. Biol. 2021, 1-13. [CrossRef]

14. Joly, M.; Amato, P.; Deguillaume, L.; Monier, M.; Hoose, C.; Delort, A.-M. Quantification of ice nuclei active at near $0{ }^{\circ} \mathrm{C}$ temperatures in low-altitude clouds at the Puy de Dôme atmospheric station. Atmos. Chem. Phys. Discuss. 2014, 14, 8185-8195. [CrossRef]

15. Morris, C.E.; Sands, D.C.; Vinatzer, B.A.; Glaux, C.; Guilbaud, C.; Buffiere, A.; Yan, S.; Dominguez, H.; Thompson, B.M. The life history of the plant pathogen Pseudomonas syringae is linked to the water cycle. ISME J. 2008, 2, 321-334. [CrossRef] [PubMed]

16. Christner, B.C.; Cai, R.; Morris, C.E.; McCarter, K.S.; Foreman, C.; Skidmore, M.L.; Montross, S.N.; Sands, D.C. Geographic, seasonal, and precipitation chemistry influence on the abundance and activity of biological ice nucleators in rain and snow. Proc. Natl. Acad. Sci. USA 2008, 105, 18854-18859. [CrossRef] [PubMed]

17. Christner, B.C.; Morris, C.E.; Foreman, C.M.; Cai, R.; Sands, D.C. Ubiquity of Biological Ice Nucleators in Snowfall. Science 2008, 319, 1214. [CrossRef]

18. Ward, P.J.; DeMott, P.J. Preliminary experimental evaluation of Snomax (TM) snow inducer, nucleus Pseudomonas syringae, as an artificial ice for weather modification. J. Weather. Modif. 1989, 21, 9-13.

19. Möhler, O.; Georgakopoulos, D.G.; Morris, C.E.; Benz, S.; Ebert, V.; Hunsmann, S.; Saathoff, H.; Schnaiter, M.; Wagner, R. Heterogeneous ice nucleation activity of bacteria: New laboratory experiments at simulated cloud conditions. Biogeosciences 2008, 5, 1425-1435. [CrossRef]

20. Wex, H.; Augustin-Bauditz, S.; Boose, Y.; Budke, C.; Curtius, J.; Diehl, K.; Dreyer, A.; Frank, F.; Hartmann, S.; Hiranuma, N.; et al. Intercomparing different devices for the investigation of ice nucleating particles using Snomax®as test substance. Atmos. Chem. Phys. Discuss. 2015, 15, 1463-1485. [CrossRef]

21. Vali, G. Quantitative Evaluation of Experimental Results and the Heterogeneous Freezing Nucleation of Supercooled Liquids. J. Atmos. Sci. 1971, 28, 402-409. [CrossRef]

22. Sands, D.C.; Schroth, M.N.; Hildebrand, D.C. Genus Pseudomonas in Laboratory Guide for Identification of Plant Pathogenic Bacteria; Schaad, N.W., Ed.; Bacteriology Committee of the American Phytopathological Society: St. Paul, MN, USA, 1980 ; pp. 36-44.

23. Steel, K.J. The Oxidase Reaction as a Taxonomic Tool. J. Gen. Microbiol. 1961, 25, 297-306. [CrossRef]

24. Klement, Z. Rapid detection of the pathogenicity of phytopathogenic pseudomonads. Nature 1963, 199, 299-300. [CrossRef]

25. Hill, T.C.; Moffett, B.F.; DeMott, P.J.; Georgakopoulos, D.G.; Stump, W.L.; Franc, G.D. Measurement of ice nucleation-active bacteria on plants and in precipitation by quantitative PCR. Appl. Environ. Microbiol. 2014, 80, 1256-1267. [CrossRef]

26. Petters, M.D.; Wright, T.P. Revisiting ice nucleation from precipitation samples. Geophys. Res. Lett. 2015, 42, 8758-8766. [CrossRef]

27. Maki, T.; Furumoto, S.; Asahi, Y.; Lee, K.C.; Watanabe, K.; Aoki, K.; Murakami, M.; Tajiri, T.; Hasegawa, H.; Mashio, A.; et al. Long-range-transported bioaerosols captured in snow cover on Mount Tateyama, Japan: Impacts of Asian-dust events on airborne bacterial dynamics relating to ice-nucleation activities. Atmos. Chem. Phys. Discuss. 2018, 18, 8155-8171. [CrossRef] 